\title{
Adrenergic effects on secretion of epidermal growth factor from Brunner's glands
}

\author{
P SKOV OLSEN, S S POULSEN, AND P KIRKEGAARD \\ From the Department of Clinical Chemistry $M L$, Department of Surgery C and Laboratory of \\ Experimental Pathology, Rigshospitalet and Department of Anatomy B, University of Copenhagen, \\ Copenhagen, Denmark
}

SUMMARY The influence of the sympathetic nervous system and adrenergic agonists on flow rate and secretion of epidermal growth factor (EGF) from Brunner's glands has been investigated in the rat. Chemical sympathectomy by administration of 6-hydroxydopamine increased volume secretion and output of EGF from Brunner's glands but depleted the glands of EGF. Infusion of noradrenaline, an alpha-adrenergic agonist, inhibited basal and vasoactive intestinal polypeptide (VIP) stimulated flow rate and output of EGF from Brunner's glands and increased the amount of EGF in the tissue. Vasoactive intestinal polypeptide also increased the amount of EGF in Brunner's gland tissue and this was unchanged after simultaneous infusion of VIP and noradrenaline as well as VIP and isoproterenol, a beta-adrenergic agonist. Isoproterenol had no effect on basal and VIP stimulated secretion of EGF from Brunner's glands. The presence of PAS-positive mucus in Brunner's glands was unchanged during infusion of noradrenaline whereas VIP induced a depletion of Brunner's gland mucus which in turn was prevented by simultaneous infusion of noradrenaline. This study indicates that the sympathetic nervous system influence the volume secretion, output of EGF and mucus content in Brunner's glands probably by activation of alpha-adrenergic pathways.

The glands of Brunner are localised in the submucosa of the proximal duodenum and experimental studies have indicated that the main function of Brunner's glands is to protect the duodenal mucosa against damage by the acid chyme ejected from the stomach. ${ }^{12}$ Duodenal ulcers are situated in the proximal duodenum in the Brunner's gland area and recent studies have demonstrated that an impaired Brunner's gland secretion might be involved in the development of experimental duodenal ulcers. ${ }^{3-5}$

The secretion from Brunner's glands contains bicarbonate, mucus and epidermal growth factor (EGF) ${ }^{67}$ Epidermal growth factor is a mitogenic peptide comprising 53 amino acids. ${ }^{8}$ The peptide is produced in the submandibular glands and Brunner's glands and is present in large amounts in urine. ${ }^{9}$ Several studies have shown an exocrine secretion of EGF from the submandibular glands and recently exocrine secretion of the peptide from Brunner's glands has been reported. ${ }^{10-12}$ Intragastric instillation of EGF increases the synthesis and

Address for correspondence: P Skov Olsen, Department Surgery C, 2122, Rigshospitalet, Blegdamsvej 9, DK-2100 Copenhagen, Denmark.

Received for publication 1 November 1984 contents of DNA and RNA in the gastroduodenal mucosa ${ }^{13}$ and intraduodenal as well as intragastric instillation of EGF prevents the development of experimental duodenal and gastric ulcers in the rat. ${ }^{14} 15$

In the submandibular glands EGF is localised to the granulated convoluted tubular cells which are innervated by adrenergic nerves and alphaadrenergic agonists stimulate exocrine secretion of EGF from the submandibular glands. ${ }^{11} 1617$ Brunner's glands are also innervated by adrenergic nerves but the effect of adrenergic agonists on secretion from Brunner's glands has not been elucidated. ${ }^{18} 19$

The present study was undertaken to investigate the influence of the sympathetic nervous system and adrenergic agonists on basal and VIP stimulated flow rate and secretion of EGF from Brunner's glands in the rat.

\section{Methods}

EXPERIMENTAL PROCEDURE

One hundred and four male Wistar rats were used, 
weighing approximately $200 \mathrm{~g}$ at the time of surgery. The rats were fasted overnight before the experiment. They had free access to water and were kept in raised meshbottom cages to prevent coprophagy. Under ether anaesthesia a $0.8 \mathrm{~mm}$ polyethylene catheter was placed in a jugular vein for infusions. For preparation of a duodenal pouch, the abdomen was opened by a midline incision. A ligature was placed around the pyloric ring, and another one 8-10 $\mathrm{mm}$ distal to the pylorus, just proximal to the entrance of the common bile and pancreatic duct. Through an incision in the distal duodenum the tip of a polyethylene catheter was introduced through the distal ligature into the duodenal pouch whereafter the ligature was tightened. For drainage of the stomach, a polyethylene catheter was placed in the stomach through a stab wound in the forestomach and secured by a purse string suture.

For collection of duodenal and gastric juice the catheters were connected to glass syringes. The rats were placed in Bollman cages and after one hour of recovery, the infusion was started. Brunner's gland secretion was collected during infusion of the following drugs for five hours in a volume of 2 $\mathrm{ml} \times \mathrm{h}^{-1}$ : noradrenaline $1.48 \mu \mathrm{mol} \times \mathrm{kg}^{-1} \times \mathrm{h}^{-1}(250$ $\left.\mu \mathrm{g} \times \mathrm{kg}^{-1} \times \mathrm{h}^{-1}\right)(\mathrm{DAK}$, Copenhagen, Denmark) and isoproterenol in a dose of $1.18 \mu \mathrm{mol} \times \mathrm{kg}^{-1} \times \mathrm{h}^{-1}(250$ $\left.\mu \mathrm{g} \times \mathrm{kg}^{-1}\right)(\mathrm{DAK}$, Copenhagen, Denmark). Porcine vasoactive intestinal polypeptide (VIP) (Gastrointestinal Hormone Unit, Karolinska Institute, Stockholm, Sweden) was infused in a dose of 330 pmol $\times \mathrm{kg}^{-1} \times \mathrm{h}^{-1}\left(1000 \mathrm{ng} \times \mathrm{kg}^{-1} \times \mathrm{h}^{-1}\right)$ alone or in combination with either noradrenaline 1.48 $\mu \mathrm{mol} \times \mathrm{kg}^{-1} \times \mathrm{h}^{-1}$ or isoproterenol $1.18 \mu \mathrm{mol} \times \mathrm{kg}^{-1}$ $\times \mathrm{h}^{-1}$. To investigate the effect of chemical sympathectomy ${ }^{20}$ on Brunner's gland secretion eight rats received an intraperitoneal injection of 6hydroxydopamine $600 \mu \mathrm{mol} \times \mathrm{kg}^{-1}\left(150 \mathrm{mg} \times \mathrm{kg}^{-1}\right)$ (Sigma Chem. Comp., St Louis, USA). After seven days Brunner's gland secretion was collected for five hours as described above during infusion of saline $(\mathrm{NaCl} 0.154 \mathrm{~mol} / \mathrm{l})$ in a volume of $2 \mathrm{ml} \times \mathrm{h}^{-1}$. Eight rats given saline served as controls.

At the end of each infusion blood was drawn from the inferior vena cava and the volume of Brunner's gland secretion was determined. The duodenal pouch was removed and together with serum stored at $-20^{\circ} \mathrm{C}$ for later determination of EGF.

For histochemical investigations of Brunner's glands rats in groups of 10 had a duodenal pouch prepared as described above. The following agents were infused in a volume of $2 \mathrm{ml}^{-1} \mathrm{~h}^{-1}$ for five hours: noradrenaline $1.48 \mu \mathrm{mol} \times \mathrm{kg}^{-1} \times \mathrm{h}^{-1}$, VIP 330 pmol $\times \mathrm{kg}^{-1} \times \mathrm{h}^{-1}$ and simultaneous infusion of the same doses of VIP and noradrenaline while 10 rats served as controls and received saline. At the end of the infusion the duodenal pouch was fixed in $10 \%$ formalin and prepared for histological investigation.

\section{LABORATORY ANALYSES}

Epidermal growth factor was measured with a homologous radioimmunoassay using antibody 8136 as described elsewhere. ${ }^{7}$ Detection limit of the assay is $0.06 \mathrm{nmol} / \mathrm{l}$ and coefficient of variation approximately 0.10 for values between $0.06 \mathrm{nmol} / \mathrm{l}$ and 4 nmol/l. Purified rat submandibular EGF was used for calibration and production of tracer. The duodenum was extracted using ion exchange chromatography as described. ${ }^{7}$ Duodenal juice and serum was tested undiluted. For evaluation of the assay, calibration curves were prepared with charcoal stripped serum and duodenal juice (unstimulated) and compared with a calibration curve performed in assay buffer. Charcoal precipitation was carried out by adding charcoal (Sigma Chem Co, St Louis, USA) $5 \mathrm{~g}$ per $100 \mathrm{ml}$ rat serum or duodenal juice. After stirring for $20 \mathrm{~min}$ at $4^{\circ} \mathrm{C}$ the suspension was separated by centrifugation at $6000 \mathrm{~g}$ for $60 \mathrm{~min}$.

\section{HISTOLOGICAL INVESTIGATIONS}

The presence of VIP-containing nerves in Brunner's glands was investigated immunohistochemically. Five rats were fixed by perfusion with $4 \%$ paraformaldehyde. The duodenum was removed and postfixed in paraformaldehyde for 24 hours. The tissues were then rinsed for 48 hours in $20 \%$ sucrose and frozen in melting freon. Cryostat sections $10 \mu \mathrm{m}$ in thickness were cut at $-20^{\circ} \mathrm{C}$. Sections were stained for VIP by the peroxidase-antiperoxidase technique (PAP) ${ }^{21}$ The VIP antiserum (Cambridge Research Biochemicals, UK) was diluted 1:400 and $1: 1600$. For controls the sections were incubated with non-immune rabbit serum and the primary antiserum preabsorbed with excess amounts of porcine VIP $10 \mu \mathrm{g} / \mathrm{ml}$. To evaluate the amount of mucus in Brunner's glands, histologic sections were stained with PAS-haematoxylin-aurentia.

\section{STATISTICS}

For statistical evaluation of the data, the MannWhitney U-test was used. P-values of $\leqslant 0.05$ were considered to be significant. All results are given as median and total range.

\section{Results}

Infusion of noradrenaline, an alpha-adrenergic agonist, reduced the spontaneous secretion from Brunner's glands. The contents of EGF in Brunner's gland tissue, however, increased whereas the total output of EGF decreased since the concentration of EGF in duodenal juice was unchanged. In contrast 
infusion of the beta-adrenergic agonist, isoproterenol, did not result in changes in comparison with controls (Table 1, Fig. 1). Chemical sympathectomy by 6-hydroxydopamine increased the secretory rate as well as the total output of EGF in duodenal juice whereas the amount of EGF in the tissue decreased (Table 1, Fig. 1). Vasoactive intestinal polypeptide increased Brunner's gland secretion and the total output of EGF but in contrast with sympathectomy the contents of EGF in the tissue were increased. The stimulatory effect of VIP was counteracted by simultaneous infusion of noradrenaline but the amount of EGF in the duodenal tissue was the same as after infusion of VIP alone (Table 2, Fig. 2). Isoproterenol had no effect on VIP stimulated Brunner's gland secretion nor on the output of EGF and the amount of peptide in the tissue was unchanged. None of the groups investigated had a median concentration of EGF serum above the detection limit of the assay.

The calibration curves prepared in serum and duodenal juice were identical (Fig. 1). Because of non-specific interference, however, a higher zerobinding was found compared with the buffer calibration curve. No indications of the presence of EGF degrading factors in serum or duodenal juice was found because the buffer calibration curve could be superimposed on the calibration curve performed in serum and duodenal juice. In no instance the background was higher than $0.5 \%$ of the total counts bound.

Immunohistochemically, VIP containing nerve fibres were found in Brunner's glands (Fig. 4). The nerve fibres were seen in close association with the secretory acini of Brunner's glands. No immunoreaction was observed in sections incubated with the primary antiserum preabsorbed with excess amounts of porcine VIP nor in sections incubated

Table 1 Effect of adrenergic agonists and 6-hydroxydopamine on secretion fromBrunner's glands

\begin{tabular}{|c|c|c|c|c|c|}
\hline Treatment & No & $\begin{array}{l}\text { Volume } \\
\mathrm{ml} / 5 \mathrm{~h}\end{array}$ & $\begin{array}{l}\text { EGFin } \\
\text { duodenal } \\
\text { juice } \\
\text { pmol/l }\end{array}$ & $\begin{array}{l}\text { EGF } \\
\text { output } \\
\text { fmoll } \\
5 \mathrm{~h}\end{array}$ & $\begin{array}{l}\text { EGF in } \\
\text { duodenum } \\
\text { fmoll } \\
\text { duodenum }\end{array}$ \\
\hline $\begin{array}{c}\text { Control } \\
\text { (saline) }\end{array}$ & 8 & $\begin{array}{l}0.95 \\
(0.70-1.40)\end{array}$ & $\begin{array}{l}260 \\
(95-470)\end{array}$ & $\begin{array}{l}220 \\
(130-390)\end{array}$ & $\begin{array}{l}425 \\
(275-625)\end{array}$ \\
\hline $\begin{array}{l}\text { Noradre- } \\
\text { naline }\end{array}$ & 8 & $\begin{array}{l}0.40+ \\
(0.20-0.55)\end{array}$ & $\begin{array}{l}265 \\
(150-650)\end{array}$ & $\begin{array}{l}105^{*} \\
(50-260)\end{array}$ & $\begin{array}{l}1075 \dagger \\
(815-1475)\end{array}$ \\
\hline $\begin{array}{l}\text { Isopro- } \\
\text { terenol }\end{array}$ & 8 & $\begin{array}{l}1.05 \\
(0 \cdot 65-1 \cdot 20)\end{array}$ & $\begin{array}{l}205 \\
(105-645)\end{array}$ & $\begin{array}{l}235 \\
(115-420)\end{array}$ & $\begin{array}{l}550 \\
(225-700)\end{array}$ \\
\hline $\begin{array}{r}\text { 6-hydroxy- } \\
\text { dopamine }\end{array}$ & & $\begin{array}{l}1.55^{*} \\
(1.30-1.90)\end{array}$ & $\begin{array}{l}650 \dagger \\
(355-910)\end{array}$ & $\begin{array}{l}1005{ }^{\dagger} \\
(515-1365)\end{array}$ & $\begin{array}{l}225^{*} \\
(<60-400)\end{array}$ \\
\hline
\end{tabular}

Values are given as median and total range. ${ }^{*}: \mathrm{p}<0.05$ and $t: p<0.01$ as compared with control.

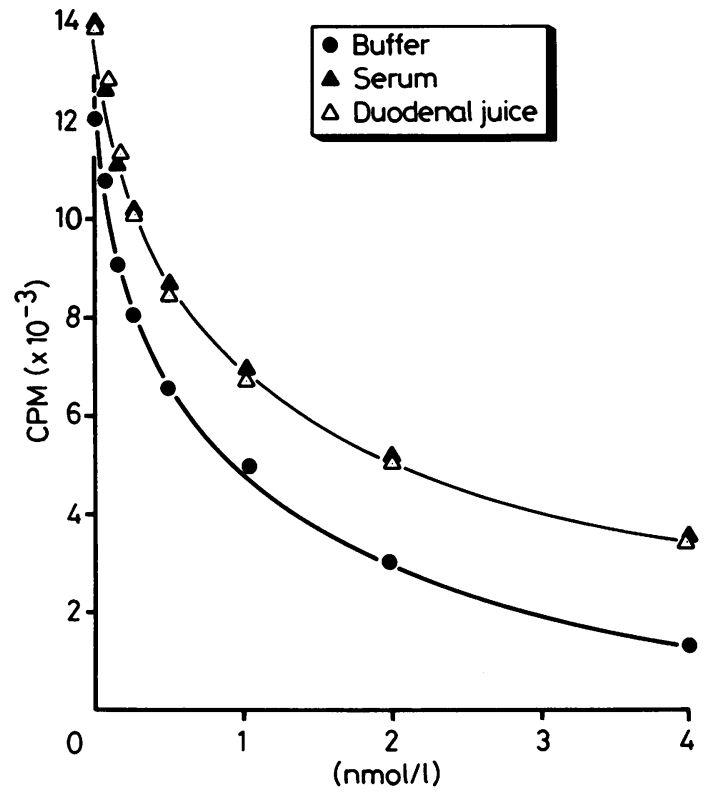

Fig. 1 Standard calibration curves for rat epidermal growth factor radioimmunoassay prepared in buffer, rat serum and rat duodenal juice.

with non-immune rabbit serum. At histological examination, Brunner's glands in the control group was rich in PAS-positive mucin and the presence of mucus was identical after infusion of noradrenaline. After infusion of VIP the main part of the secretory acini became PAS-negative and thus depleted of mucus. This effect of VIP was partly prevented by simultaneous infusion of noradrenaline (Figs. 5 and 6).

Table 2 Effect of adrenergic agonists on VIP stimulated secretion from Brunner's glands

\begin{tabular}{|c|c|c|c|c|c|}
\hline Treatment & No & $\begin{array}{l}\text { Volume } \\
\mathrm{ml} / 5 \mathrm{~h}\end{array}$ & $\begin{array}{l}\text { EGF in } \\
\text { duodenal } \\
\text { juice } \\
\text { pmol/l }\end{array}$ & $\begin{array}{l}E G F \\
\text { output } \\
\text { fmoll } \\
5 h\end{array}$ & $\begin{array}{l}\text { EGF in } \\
\text { duodenum } \\
\text { fmol/ } \\
\text { duodenum }\end{array}$ \\
\hline $\begin{array}{c}\text { Control } \\
\text { (saline) }\end{array}$ & 8 & $\begin{array}{l}0.95 \\
(0 \cdot 70-1 \cdot 40)\end{array}$ & $\begin{array}{l}260 \\
(95-470)\end{array}$ & $\begin{array}{l}220 \\
(130-390)\end{array}$ & $\begin{array}{l}425 \\
(275-625)\end{array}$ \\
\hline VIP & 8 & $\begin{array}{l}1 \cdot 90 \dagger \\
(1 \cdot 60-2 \cdot 15)\end{array}$ & $\begin{array}{l}320 \\
(200-415)\end{array}$ & $\begin{array}{l}620^{*} \\
(340-730)\end{array}$ & $\begin{array}{l}650^{*} \\
(475-950)\end{array}$ \\
\hline $\begin{array}{l}\text { VIP+nor- } \\
\text { adrenaline }\end{array}$ & $e^{8}$ & $\begin{array}{l}0 \cdot 75 \ddagger \\
(0 \cdot 50-0.90)\end{array}$ & $\begin{array}{l}220 \\
(150-315)\end{array}$ & $\begin{array}{l}165^{*} \\
(90-245)\end{array}$ & $\begin{array}{l}800 \dagger \\
(525-1250)\end{array}$ \\
\hline $\begin{array}{l}\text { VIP+iso- } \\
\text { protereno }\end{array}$ & 8 & $\begin{array}{l}2 \cdot 00 \\
(1 \cdot 20-2 \cdot 60)\end{array}$ & $\begin{array}{l}305 \\
(170-535)\end{array}$ & $\begin{array}{l}730 \\
(410-1070)\end{array}$ & $\begin{array}{l}725 t \\
(425-1075)\end{array}$ \\
\hline
\end{tabular}

Values are given as median and total range. ${ }^{*}: p<0.05$ and $\dagger: p<0.01$ as compared with controls; $\ddagger: p<0.01$ as compared with infusion of VIP. 


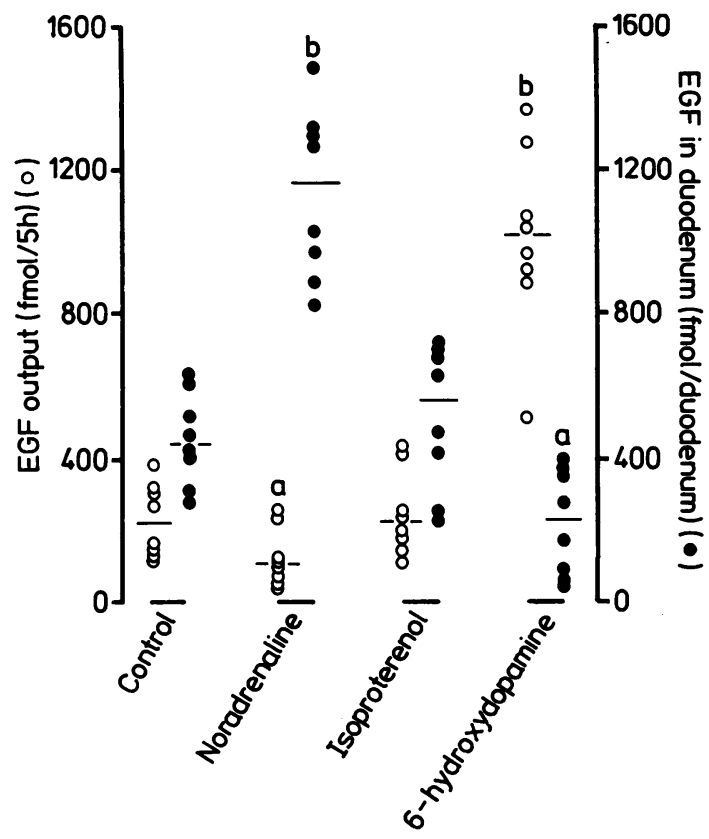

Fig. 2 Effect of adrenergic agonists and chemical sympathectomy (6-hydroxydopamine) on total output of EGF from Brunner's glands and the corresponding amount of $E G F$ in the duodenum at the end of the experiment are shown. $a: p<0.05$ and $b: p<0.01$ as compared with control. (Median and total range of eight rats).

\section{Discussion}

Previous investigations have shown that a humoral mechanism is important in regulation of secretion from Brunner's glands. ${ }^{622}$ A nervous effect on the secretion has also been reported. ${ }^{2324}$ Wright et al demonstrated a cholinergic control of Brunner's gland secretion as cholinomimetic agents and direct stimulation of the cut ends of the vagal nerve stimulates Brunner's gland secretion. The latter effect could be eliminated by infusion of atropine. ${ }^{23}$

While the vagal nerve was supposed to stimulate Brunner's gland secretion the sympathetic nervous system has been suggested to reduce the secretion because electrical stimulation of the splanchnic nerves reduced the secretory output from the glands, while section of the splanchnic nerves increased the secretion. ${ }^{23}$ The latter effect could also be prevented by atropine indicating that the splanchnic nerves carries inhibitory fibres which influence a cholinergic tonus on Brunner's glands.

In the present study the inhibitory effect of the sympathetic nervous system on the Brunner's gland secretion was confirmed. Chemical sympathectomy

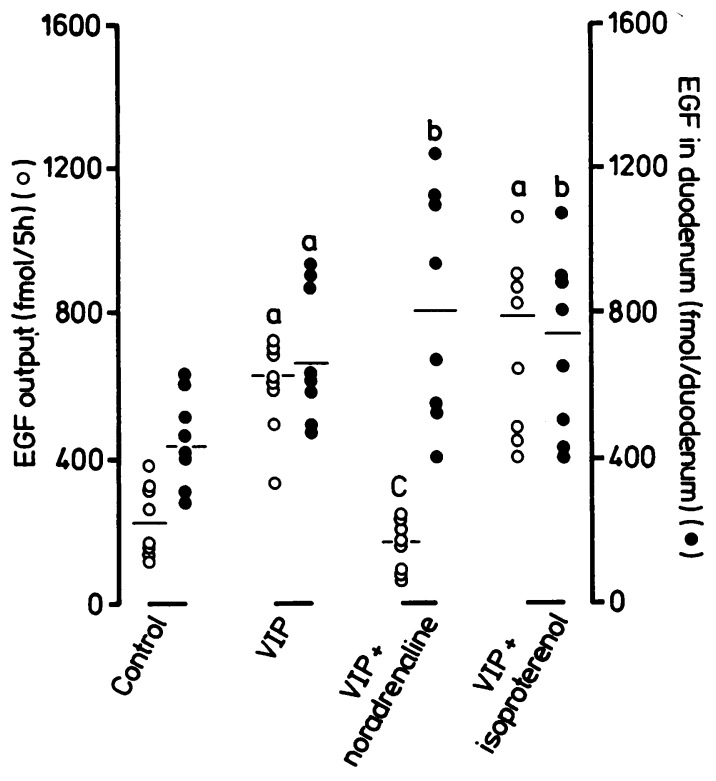

Fig. 3 Effect of adrenergic agonists on VIP stimulated secretion from Brunner's glands. The total output of EGF from Brunner's glands and the corresponding amount of $E G F$ in the duodenum at the end of the experiment are shown. $a: p<0.05$ and $b: p<0.01$ as compared with control; $c: p<0.01$ as compared with infusion of VIP. (Median and total range of eight rats).

with 6-hydroxydopamine increased the flow rate and output of EGF from Brunner's glands whereas the alpha-adrenergic agonist, noradrenaline, inhibited the secretion. These results are consistent with the finding of adrenergic nerves surrounding the secretory acini of Brunner's glands which suggests a functional adrenergic innervation of the glands. ${ }^{18}$

In this study we confirm the previous finding of VIP containing nerves in Brunner's glands in the rat. ${ }^{27}$ By means of the conventional PAP technique used in the present study we found VIP containing nerves between the glands and in close association to the secretory acini (Fig. 4) suggesting a VIP-ergic innervation of the rat Brunner's glands. Vasoactive intestinal polypeptide was found to increase Brunner's gland secretion, total output of EGF and to increase the contents of EGF in the glands. In contrast noradrenaline inhibited VIP stimulated secretion of EGF but did not influence the increased amount of EGF in the tissue observed after infusion of VIP. This and the observed effect of noradrenaline and chemical sympathectomy on secretion and contents of EGF in Brunner's glands (Figs. 2 and 3) suggests that the adrenergic nerves innervating 


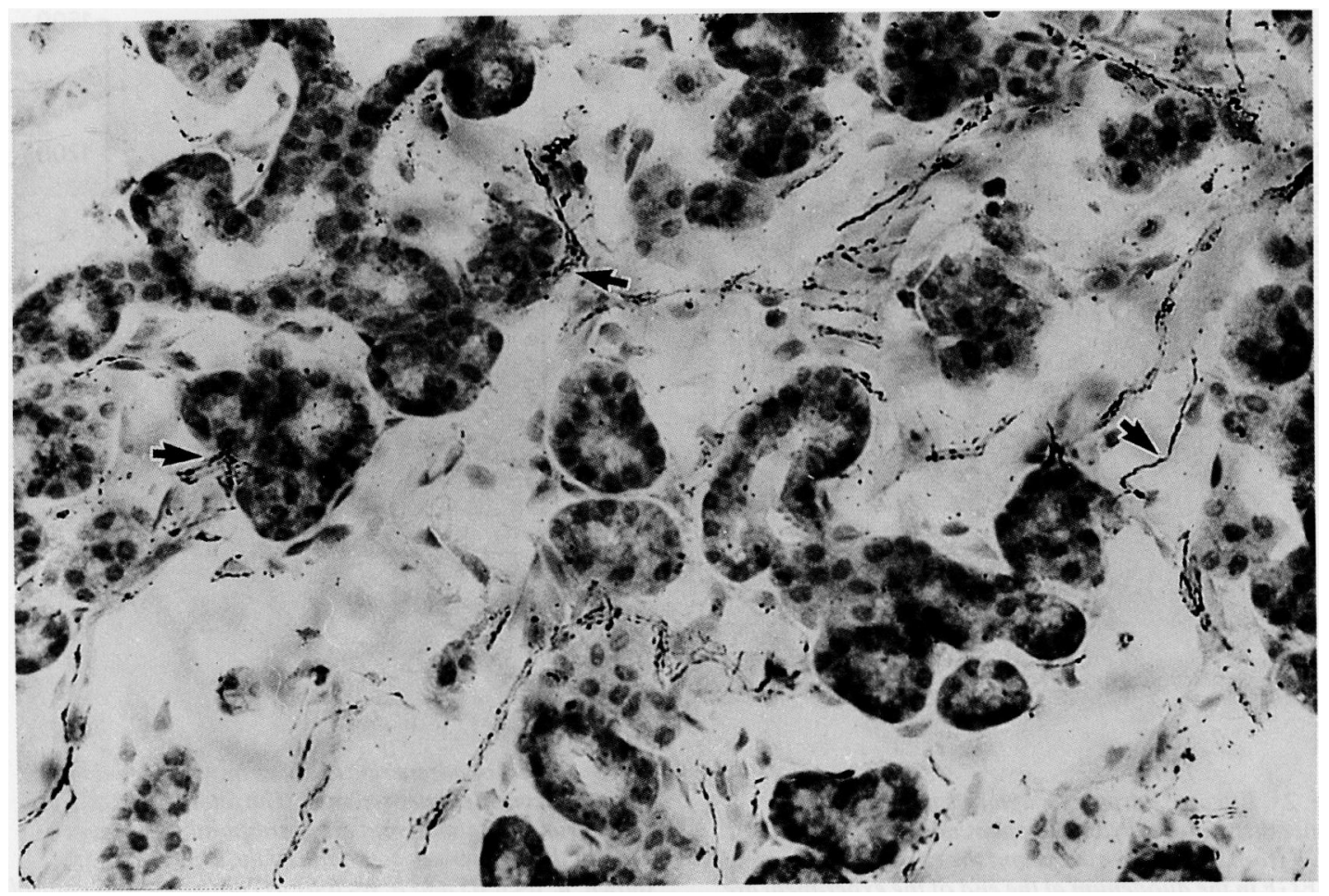

Fig. 4 VIP immunoreactive nerves in Brunner's glands of the rat visualised by means of the peroxidase-antiperoxidase (PAP) technique. The VIP immunoreactive fibres are found between the secretory acini and in close association to these (arrows) (×335).

Brunner's glands mainly influence the release of EGF though the possibility of an increased synthesis of EGF cannot be excluded. On the other hand it seems likely that VIP increases the synthesis of EGF as VIP induced secretion does not deplete the glands from EGF.

Substantial evidence has accumulated showing that cholinergic, adrenergic and VIP-containing nerves innervate and thereby influence the secretion from Brunner's glands. ${ }^{18} 2324$ A coexistence of VIP and acetylcholine in secretory nerves has been reported in the cat submandibular gland and combined biochemical and functional studies have indicated that acetylcholine probably acts as a classical neurotransmitter, while VIP serves as a neuromodulator that increases the affinity of the receptor to acetylcholine. ${ }^{25} \mathrm{~A}$ similar effect on rat Brunner's glands has been suggested as combined infusion of VIP and acetylcholine has a more potent effect on the output of EGF than infusion of each of the substances alone and furthermore the VIP induced secretion from the glands can be prevented by atropine. ${ }^{12}$ Atropine has, however, also been found to prevent the increased secretion from Brunner's glands after section of the greater splanchnic nerves $^{23}$ and the observed effect of noradrenaline and chemical sympathectomy in the present study suggests adrenergic nerves to have an inhibitory effect on Brunner's gland secretion. Furthermore, VIP has previously been shown not only to increase the secretion but also to deplete Brunner's glands of mucus. ${ }^{24}$ We found noradrenaline to prevent the VIP induced depletion of mucus from Brunner's glands indicating that noradrenaline inhibits not only the flow rate and secretion of EGF but also influence the secretion of mucus.

In the present study exocrine secretion of EGF was observed. Both mucus and EGF is thought to be protective factors in the gastroduodenal mucosa ${ }^{26} 27$ and a decrease in the exocrine secretion of EGF from Brunner's glands has been observed during the development of experimental duodenal ulcers. ${ }^{14}$ The role of the sympathetic nervous system in protection of the gastroduodenal mucosa is un- 

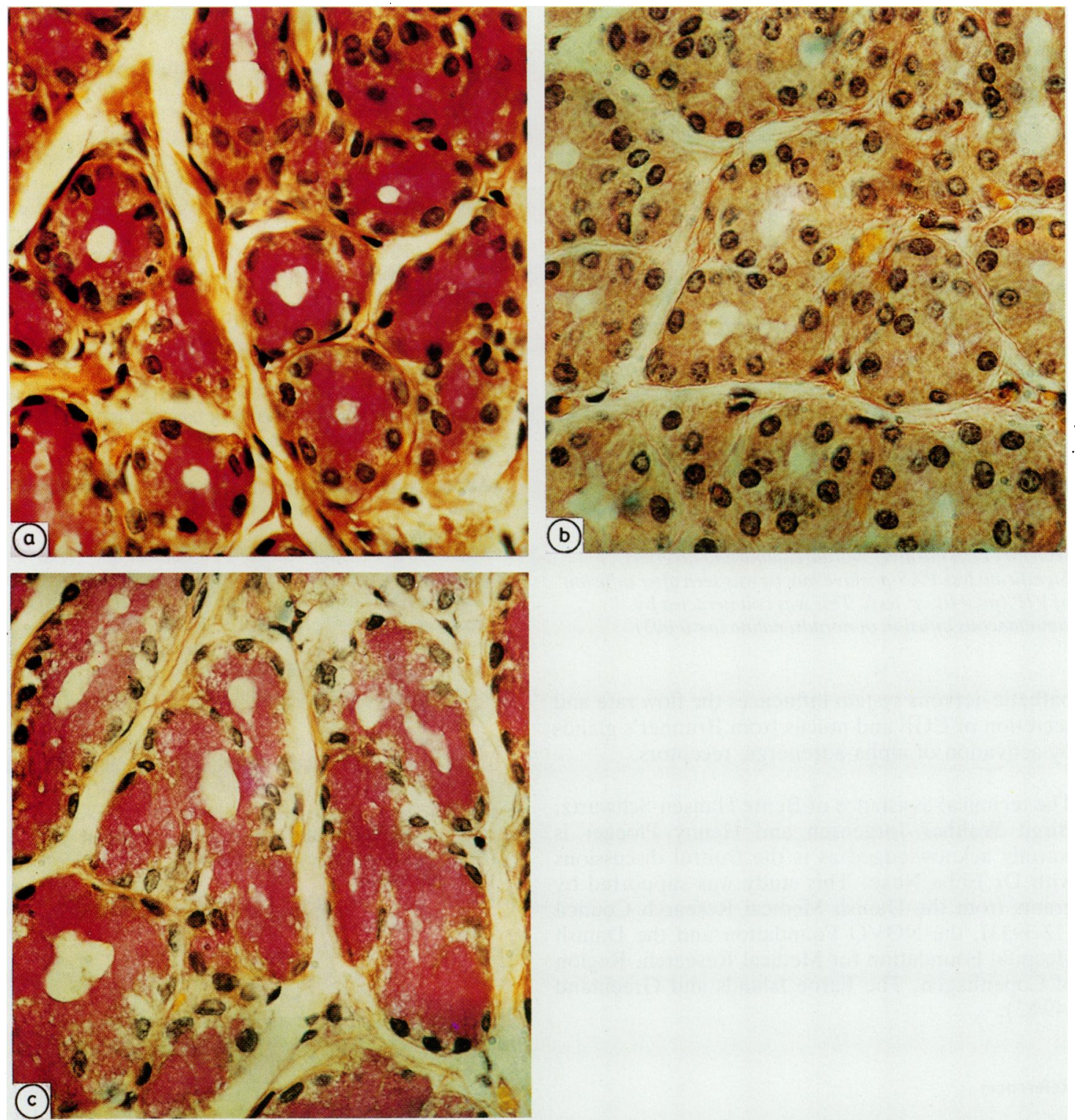

Fig. 5 PAS-positive mucus in the secretory acini of Brunner's glands. (a) control. (b) after infusion of vasoactive intestinal polypeptide VIP $330 \mathrm{pmol} \times \mathrm{kg}^{-1} \times \mathrm{h}^{-1}$ for five hours and (c) following infusion of VIP and noradrenaline 1.48 umol $\times$ $\mathrm{kg}^{-1} \times \mathrm{h}^{-1}$ for five hours. Infusion of VIP is followed by depletion of mucus. This effect is counteracted by simultaneous infusion of noradrenaline. PAS-haematoxylin-aurentia $(\times 550)$.

known. The observed effect of noradrenaline and sympathectomy on the amount of mucus and EGF in Brunner's glands and the effect on the output of EGF from the glands suggests that an increased activity in the sympathetic nervous system or an increased level or circulating catecholamines would decrease the protection of the duodenal mucosa and thereby facilitate the development of duodenal ulcers.

In conclusion, this study suggests that the sym- 


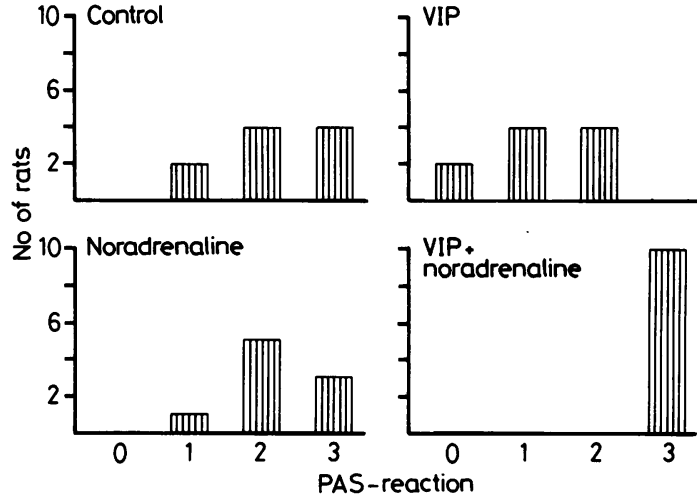

Fig. 6 PAS-reaction for mucus in the secretory cells of Brunner's glands after infusion of noradrenaline 1.48 umol $\times \mathrm{kg}^{-1} \times \mathrm{h}^{-1}$,VIP $330 \mathrm{pmol} \times \mathrm{kg}^{-1} \times \mathrm{h}^{-1}$ and simultaneous infusion of both VIP and noradrenaline. Grading of $P A S$-reaction: $0=P A S$-negative; $1=1-2$ small glandular areas with $P A S$ positive reaction; $2=$ more than two small areas PAS-positive, but not the whole gland; $3=$ all secretory cells positive. Noradrenaline had no effect. Significant less $P A S$-positive mucus was seen after infusion of $\operatorname{VIP}\left(p<0.01, \chi^{2}\right.$ test $)$. This was counteracted by simultaneous infusion of noradrenaline $(p<0.005)$.

pathetic nervous system influences the flow rate and secretion of EGF and mucus from Brunner's glands by activation of alpha-adrenergic receptors.

The technical assistance of Bente Hansen-Schwartz, Birgit Walther Jørgensen and Henny Ploeger is warmly acknowledged as is the fruitful discussions with Dr Ebba Nexø. This study was supported by grants from the Danish Medical Research Council (12-3933), the NOVO Foundation and the Danish Hospital Foundation for Medical Research. Region of Copenhagen, The Faroe Islands and Greenland $(49 / 83)$

\section{References}

1 Florey HW, Jennings MA, Jennings DA, Casteo O'Connor $\mathrm{R}$. The reactions of the intestine of the pig to gastric juice. J Pathol Bacteriol 1939; 49: 105-23.

2 Griffith CA, Harkins HN. The role of Brunner's glands in the intrinsic resistance of the duodenum to acidpeptic digestion. Ann Surg 1956; 243: 160-72.

3 Hartiala K, Ivy AC, Grossman MI. Effect of feeding cinchophen on secretion of juice by duodenal glands in dog. Am J Physiol 1950; 162: 110-4.

4 Perkins WE, Green TJ. Effect of 3,4-toluenediamine on output from in situ rat Brunner's glands pouches. Proc Soc Exp Biol Med 1975; 149: 991-4.

5 Kirkegaard P, Poulsen SS, Halse C, Loud FB, Skov Olsen P, Christiansen J. The effect of cysteamine on the Brunner gland secretion in the rat. Scand $J$ Gastroenterol 1981; 16: 93-6.

6 Kirkegard P, Skov Olsen P, Poulsen SS, Holst JJ, Schaffalitsky de Muckadell OB, Christiansen J. Effect of secretin and glucagon on Brunner's gland secretion in the rat. Gut 1984; 25: 264-8.

7 Skov Olsen P, Nexø E. Quantitation of epidermal growth factor in the rat. Identification and partial characterization of duodenal EGF. Scand $J$ Gastroenterol 1983; 18: 771-6.

8 Gregory $\mathrm{H}$. Isolation and structure of urogastrone and its relationship to epidermal growth factor. Nature 1975; 257: 325-7.

9 Hollenberg MD. Epidermal growth factorurogastrone, a polypeptide acquiring hormonal status. Vitam Horm 1979; 37: 69-110.

10 Murphy RA, Pantazis NJ, Papastavros M. Epidermal growth factor and nerve growth factor in mouse saliva: a comparative study. Develop Biol 1979; 71: 356-70.

11 Skov Olsen P, Kirkegaard P, Poulsen SS, Nexø E. Adrenergic effects on exocrine secretion of rat submandibular epidermal growth factor. Gut 1984; 25: $1234-40$.

12 Kirkegaard P, Skov Olsen P, Poulsen SS, Nexø E. Exocrine secretion of epidermal growth factor from Brunner's glands. Stimulation by VIP and acetylcholine. Regulatory Peptides 1983; 7: 367-72.

13 Dembinski A, Gregory H, Konturek SJ, Polanski M. Trophic action of epidermal growth factor on the pancreas and gastroduodenal mucosa in rats. $J$ Physiol 1982; 325: 35-42.

14 Kirkegaard P, Skov Olsen P, Poulsen SS, Nexø E. Epidermal growth factor inhibits cysteamine-induced duodenal ulcers. Gastroenterology 1983; 85: 1277-83.

15 Skov Olsen P, Poulsen SS, Kirkegaard P, Nexø E. The role of submandibular saliva and epidermal growth factor in gastric cytoprotection. Gastroenterology 1984; 87: 103-8.

16 Gresik EW, Van der Noen H, Barka T. Epidermal growth factor-like material in rat submandibular gland (1). Am J Anat 1979; 156: 83-9.

17 Alm P, Bloom GD, Carlsöö B. Adrenergic and cholinergic nerves of bovine, Guinea pig and hamster salivary glands. A light and electron microscopic study. $Z$ Zellforsch 1973; 138: 407-20.

18 Stach VW, Hung N. Light microscopic and histochemical results on the innervation of Brunner's glands in the duodenum of laboratory animals. Anat Anz 1978; 144: 253-35.

19 Hartiala KJV, Toivonen T. Studies on the effect of adrenaline and noradrenaline on the duodenal secretion in dog. Acta Physiol Scand 1954; 31: 125-30.

20 Thoenen H, Tranzer JP. Chemical sympathectomy by selective destruction of adrenergic nerve endings with 6-hydroxydopamine. Naunyn-Schmiedebergs Arch Pharmacol 1968; 261: 271-8.

21 Sternberger L. In: Immunohistochemistry Englewood Cliffs, New York: Prentice Hall, 1974: 129-171.

22 Florey HW, Harding HE. A humoral control of the secretion of Brunner's glands. Proc $R$ Soc Lond B 1935; 117: 68-77.

23 Wright RD, Jennings MA, Florey HW, Lium R. The 
influence of nerves and drugs on secretion by the small intestine and an investigation of the enzymes in intestinal juice. $Q J$ Exp Physiol 1940; 166: 73-120.

24 Kirkegaard P, Lundberg JM, Poulsen SS, Skov Olsen P, Fahrenkrug J, Hökfelt T, Christiansen J. Vasoactive intestinal polypeptidergic nerves and Brunner's gland secretion in the rat. Gastroenterology 1981; 81: 872-8.

25 Lundberg JM. Evidence for coexistence of vasoactive intestinal polypeptide (VIP) and acetylcholine in neurons of cat exocrine glands. Morphological, biochemical and functional studies. Acta Physiol Scand 1981; suppl: 496: 1-57.

26 Allen A, Garner A. Mucus and bicarbonate secretion in the stomach and their possible role in mucosal protection. Gut 1980; 21: 249-62.

27 Konturek SJ, Radecki T, Brzozowski T et al. Gastric cytoprotection by epidermal growth factor. Gastroenterology 1981; 81: 438-43. 